\title{
MULTI-WALLED CARBON NANOTUBES EFFECT IN POLYPROPYLENE NANOCOMPOSITES
}

\author{
VPLIV VEČSTENSKIH OGLJIKOVIH NANOCEVK \\ V NANOKOMPOZITIH IZ POLIPROPILENA
}

\author{
Cristina-Elisabeta Ban ${ }^{1,2}$, Adriana Stefan'1, Ion Dinca1, George Pelin ${ }^{1,2}$, \\ Anton Ficai ${ }^{2}$, Ecaterina Andronescu' ${ }^{2}$, Ovidiu Oprea ${ }^{2}$, Georgeta Voicu ${ }^{2}$ \\ ${ }^{1}$ National Institute for Aerospace Research "Elie Carafoli" Bucharest, Materials Unit, 220 Iuliu Maniu Blvd, 061126 Bucharest, Romania \\ ${ }^{2}$ University Politehnica of Bucharest, Faculty of Applied Chemistry and Materials Science, 1-7 Polizu St., 011061 Bucharest, Romania \\ ban.cristina@incas.ro
}

Prejem rokopisa - received: 2014-07-31; sprejem za objavo - accepted for publication: 2015-02-06

doi:10.17222/mit.2014.142

\begin{abstract}
The paper presents a study concerning thermoplastic nanocomposites having polypropylene as the matrix and different contents of carboxyl-functionalized multi-walled carbon nanotubes as the nanofiller. The materials are obtained by melt compounding the nanofiller powder and polymer pellets through the extrusion process followed by injection molding into specific-shape specimens. The materials are evaluated in terms of mechanical properties such as the tensile and flexural strengths and moduli, the thermal stability under load (the heat deflection temperature) and the thermal-behavior properties using a TG-DSC analysis. The fracture cross-section is analyzed using FTIR spectroscopy and SEM microscopy to evaluate the bulk characteristics of the materials. The results show positive effects of the nanofiller addition to the thermoplastic polymer on the mechanical strength and modulus of the materials during flexural and tensile tests, while in the case of the thermal stability under load, the nanofiller addition has a minor influence on the heat-deflection-temperature values.
\end{abstract}

Keywords: polypropylene, melt mixing, carbon nanotubes, mechanical properties, thermal resistance

Članek predstavlja študijo termoplastičnih nanokompozitov s polipropilensko osnovo in različno vsebnostjo s karboksilom obdelanih, večstenskih ogljikovih nanocevk kot nanopolnilom. Materiali so bili dobljeni iz taline, sestavljene iz prahu nanopolnila in peletov polimerov, s postopkom ekstruzije, ki mu je sledilo tlačno litje vzorcev. Materiali so ocenjeni glede mehanskih lastnosti, kot so natezna in upogibna trdnost in moduli, toplotne stabilnosti pri obremenitvi (deformacijska toplota) in toplotne značilnosti z uporabo TG-DSC analize. Za oceno značilnosti osnovnega materiala je bil analiziran prelom s pomočjo FTIR spektroskopije in SEM mikroskopije. Rezultati kažejo pozitivne učinke vpliva dodatka nanopolnila termoplastičnemu polimeru na mehansko trdnost in module materiala pri upogibnem in nateznem preizkusu, medtem ko ima dodatek nanopolnila manjši vpliv na vrednosti deformacijske toplote pri obremenitvi.

Ključne besede: polipropilen, mešanje taline, ogljikove nanocevke, mehanske lastnosti, toplotna obstojnost

\section{INTRODUCTION}

Polymer nanocomposites found applications in a wide variety of fields, from microelectronics to aerospace. ${ }^{1}$ Carbon nanotube-based polymer composites combine the good processability of the matrix with the remarkable functional properties of these nanofillers. Multi-walled-carbon-nanotube (MWCNT) filled isotactic polypropylene (PP) nanocomposites can be obtained through several processing methods, such as melt mixing, solution casting and in-situ polymerization, among them, melt mixing having some major advantages as it combines high speed and simplicity with the absence of solvents and contaminants. ${ }^{2}$ For the production of these nanocomposites, a double-screw extruder is a more appropriate device than a single-screw extruder. ${ }^{3}$ The formation of a filler network structure (Figure 1) depends on several parameters, e.g., the concentration or dispersion states of the nanotubes in the matrix. Carbon nanotubes have a tendency to form agglomerates that lead to a decrease in the surface area, consequently hindering the structure formation. ${ }^{4}$ The screw speed is a strong factor that influences the dispersion of the carbon nanotubes in polypropylene; too high a speed rate can generate a mechanical degradation of the final nanocomposite as a high shear stress can affect the nanotubes structure, while too low a speed rate may be insufficient for an aggregate disentanglement. ${ }^{4}$

Achieving a good dispersion is influenced also by the surface optimization between the two phases. The MWCNT-matrix interfacial-adhesion enhancement can be obtained by modifying the MWCNT surface through the non-covalent functionalization that maintains the nanotube structure or the covalent functionalization, such as acid treatment creating carboxyl and hydroxyl groups on the surface, that enhances the load transfer to the matrix. ${ }^{5}$ There are studies showing that properties enhancements are achieved for smaller nanotubes contents and moderate acid-treatment times. ${ }^{5,6}$

The study presents the characterization of isotactic polypropylene filled with carboxyl-functionalized MWCNT obtained through the simple melt-extrusion technique. The results show an improvement in the tensile and flexural strengths and moduli when adding 


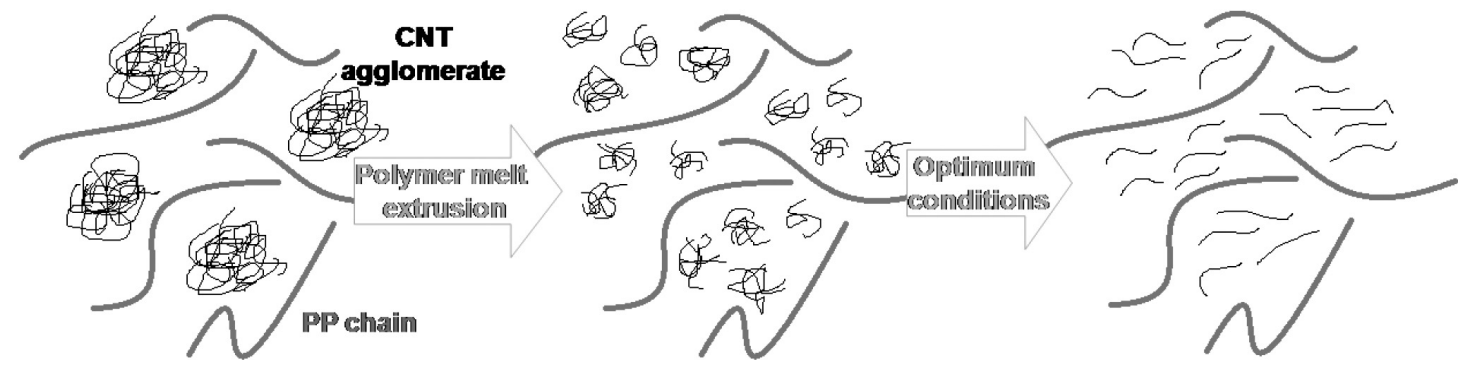

Figure 1: Exfoliated nanocomposite formation during the polymer-melt mixing

Slika 1: Nastanek ekspandiranega nanokompozita med mešanjem taline polimera

the nanofiller. In the case of a higher MWCNT loading $(w(\mathrm{MWCNT})=4 \%)$, the nanocomposites present a higher stiffness, decomposition temperature and thermal stability under load, while at a lower loading $(w(\mathrm{MWCNT})=2 \%)$ they exhibit a better mechanical strength.

\section{EXPERIMENTAL SECTION}

\subsection{Materials}

The matrix was an isotactic polypropylene (TIPPLEN H 949 purchased from Basplast SRL) of the homopolymer type with a flow index of 45 . The nanofiller was carboxyl-functionalized multi-walled carbon nanotubes of a $95 \%$ purity (Chengdu Organic Chemicals Co. Ltd, outer diameter: 10-20 nm, COOH content: $w=2.56 \%$, length: $10-30 \mu \mathrm{m}$, specific surface area: $233 \mathrm{~m}^{2} / \mathrm{g}$, density: $\left.\sim 2.1 \mathrm{~g} / \mathrm{cm}^{3}\right)$.

\subsection{Nanocomposites synthesis}

The nanocomposite samples were obtained by direct melt compounding using a twin-screw extruder (Leistritz LSM 3034 with a $34 \mathrm{~mm}$ screw diameter). The polypropylene (PP) pellets and nanofiller powder were mixed at a gradual temperature increase on the ten heating areas of the extruder, with a temperature profile between $150-170{ }^{\circ} \mathrm{C}$ and at a screw speed rate of $220 \mathrm{~min}^{-1}$. The filaments were cooled in water, chopped, dried and injected at $165-185{ }^{\circ} \mathrm{C}$ into the specimens with a specific shape. Samples of pure PP, 2 and $4 \%$ of mass fractions of MWCNT (relative to the matrix) were obtained, as higher contents favor agglomeration and lead to economically non-viable materials.

\subsection{Testing and characterization}

The nanocomposites were subjected to a spectroscopy analysis (Thermo iN10 MX, mid-infrared FTIR microscope/ATR mode) and scanning electron microscopy (SEM - HITACHI S2600N microscope), in the fracture cross-section to highlight the nanofiller presence. Tensile and flexural tests were performed using an INSTRON 5982 machine, on a minimum of 5 specimens per test, according to SR EN ISO 527- $2^{7}$ at a tensile rate of $50 \mathrm{~mm} / \mathrm{min}$, on 1A-type specimens and SR EN ISO
$178^{8}$ at a test speed of $2 \mathrm{~mm} / \mathrm{min}$, for conventional deflection on rectangular specimens. The thermal-degradation behavior was followed by TG-DSC (Netzsch TG $449 \mathrm{C}$ STA Jupiter) heating at $10 \mathrm{~K} / \mathrm{min}$, from $25-900{ }^{\circ} \mathrm{C}$, under a dried-air flow of $10 \mathrm{~mL} / \mathrm{min}$. The HDT thermal stability under load was evaluated using Qualitest HDT1 according to SR EN ISO 75 , using a $2{ }^{\circ} \mathrm{C} / \mathrm{min}$ heating rate and the standard deflection of $0.34 \mathrm{~mm}$ at a flexural stress of 1.8 MPa. The density was calculated as the ratio between mass and volume; the volume was measured using the displacement method.

\section{RESULTS AND DISCUSSION}

\subsection{FTIR spectroscopy}

Figure 2 presents the spectra of the isotactic PP in comparison with the samples nanofilled with 2 and $4 \%$ of mass fractions of MWCNT. All the spectra present the characteristic peaks of $\mathrm{PP}:-\mathrm{CH}_{2}$ and $-\mathrm{CH}_{3}$ stretching vibrations $\left(2800-2950 \mathrm{~cm}^{-1}\right)^{9},-\mathrm{CH}_{3}$ and $-\mathrm{CH}_{2}$ bending $\left(1376,1456 \mathrm{~cm}^{-1}\right)^{10,11}$, and $\mathrm{C}-\mathrm{CH}_{3}$ stretching $\left(841 \mathrm{~cm}^{-1}\right)^{10}$.

Calculating the ratio of the absorption bands at 998 and $973 \mathrm{~cm}^{-1}\left(\mathrm{~A}_{998} / \mathrm{A}_{973}\right)^{12}$ characteristic for the pure isotactic PP, the isotacticity index for the PP used in this study was $77.8 \%$.

There are some differences between the MWCNT samples due to the matrix-nanofiller interaction. ${ }^{13}$ Between 1000-1100 $\mathrm{cm}^{-1}$ the signals are more intense, probably due to the $\mathrm{C}=\mathrm{O}$ bonding from the $\mathrm{COOH}$

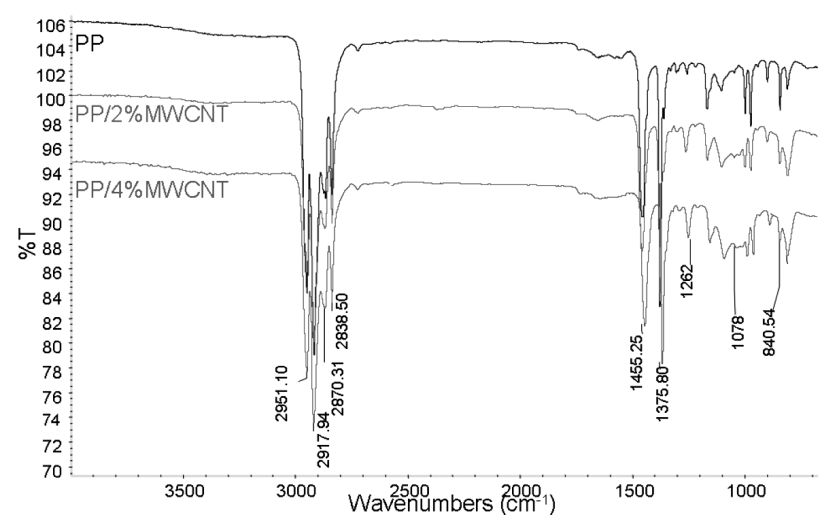

Figure 2: FTIR spectra of the polypropylene-based nanocomposites Slika 2: FTIR-spektri nanokompozitov na osnovi polipropilena 


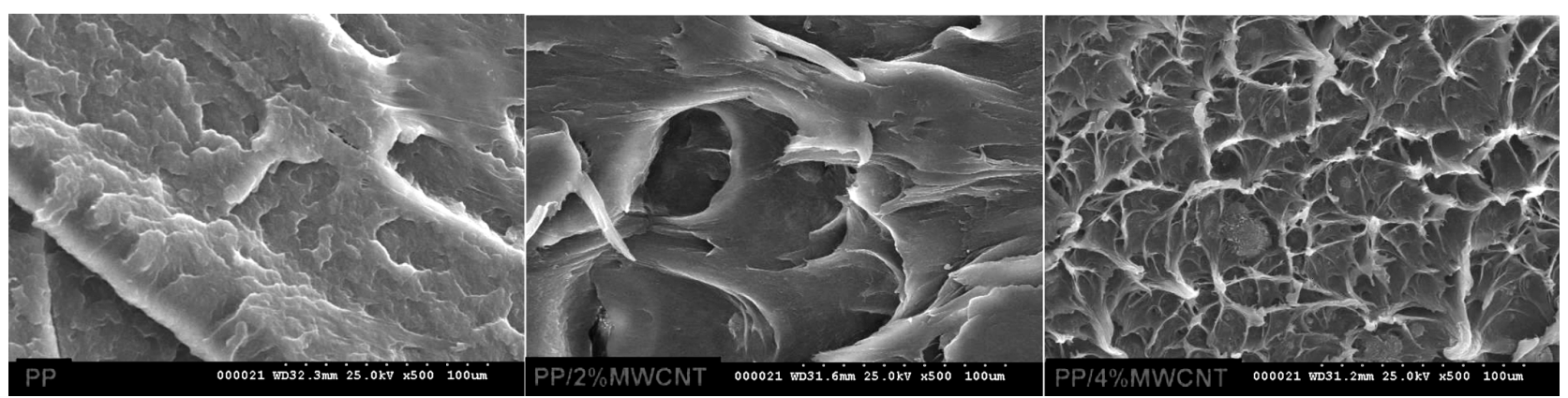

Figure 3: SEM images of PP-based nanocomposites compared to simple PP, at 500× magnification Slika 3: SEM-posnetki nanokompozitov na osnovi PP v primerjavi z enostavnim PP, pov. 500×

functionalization. ${ }^{14}$ The increase in the signal intensity at $1078 \mathrm{~cm}^{-1}$ can be due to the stretching vibration of C-O. ${ }^{15}$ Minor differences appear at $1500-1750 \mathrm{~cm}^{-1}$, more visible in the $4 \%$ of mass fractions of MWCNT$\mathrm{COOH}$ samples; the weak peak at approximately 1738 $\mathrm{cm}^{-1}$ can be due to the $\mathrm{C}=\mathrm{O}$ stretching vibration from the $\mathrm{COOH}$ group $^{15}$ and the modifications at $1550 \mathrm{~cm}^{-1}$ to the $\mathrm{OH}$ groups in $\mathrm{C}-\mathrm{OH}$ from the nanotubes treatment. ${ }^{16}$

Minor differences between the FTIR spectra can be due to the low MWCNT content or a weak connection with the polymer, probably because of the non-polar nature of the polypropylene.
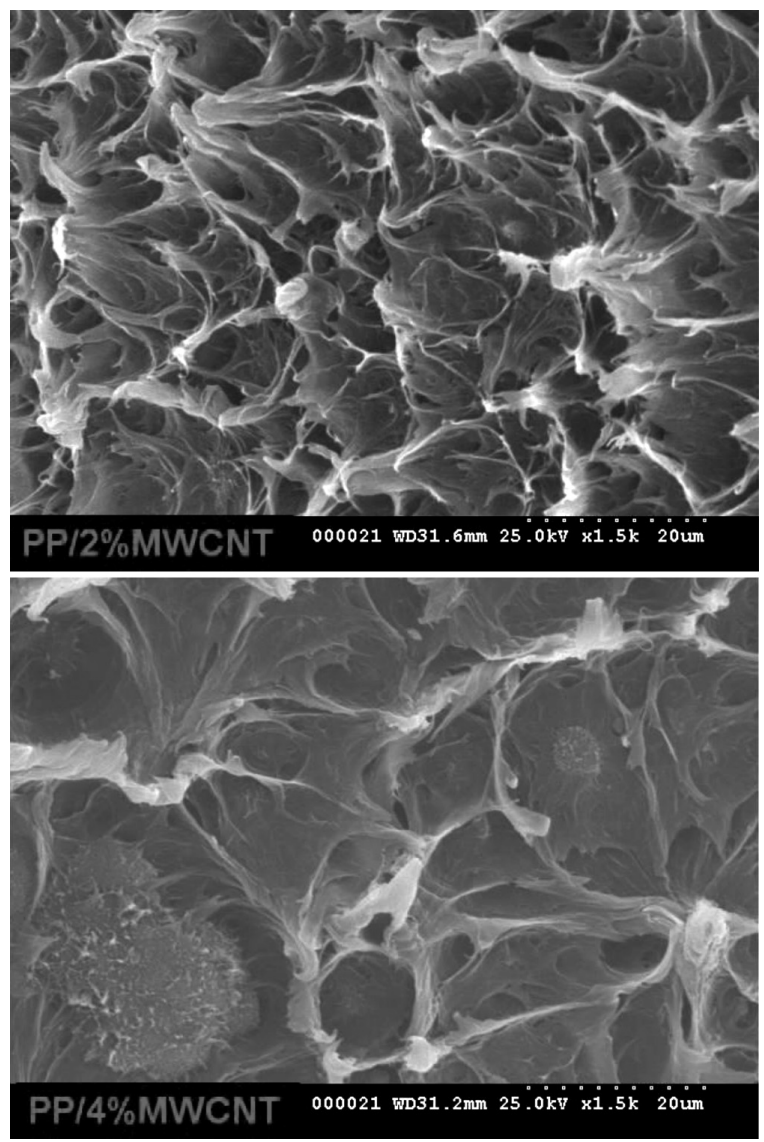

Figure 4: SEM images of PP-based nanocomposites at $1500 \times$ magnification

Slika 4: SEM-posnetka nanokompozitov na osnovi PP, pov. 1500×

\subsection{SEM electronic microscopy}

SEM highlights the sample morphology at different magnifications. The cross-section is strongly influenced by the nanofiller, presenting visible edges and cracks prior to the tensile-test fracture. The fracture area of the samples with $w(\mathrm{MWCNT})=2 \%$ is rougher, more like the simple PP than the ones with $w($ MWCNT) $=4 \%$, due to the lower nanofiller content. At a $500 \times$ magnification, a good dispersion of MWCNT can be noticed (Figure 3). In PP/2 \% MWCNT there are some pores, probably as impurities from the carbon nanotubes. In the case of PP/4 \% MWCNT there are no visible pores, but there are some non-uniform areas, most likely due to the higher nanofiller content that increases the agglomeration tendencies. In the case of PP/4 \% MWCNT, fracture-initiation sites can be observed (Figure 4).

\subsection{Mechanical testing}

Figure 5 presents the stress-strain curves of the replicas of the mediated specimens corresponding to the samples. Figure 6 presents the load-extension evolution, illustrating that during the flexural test the materials mainly exhibit the same behavior; in the first stage, $\mathrm{PP} / 2 \% \mathrm{MWCNT}$ followed the PP trend, then its line was the same as the one for PP/4 \% MWCNT.

Table 1 presents the summary of the mechanical and heat-deflection results. The nanocomposites exhibit

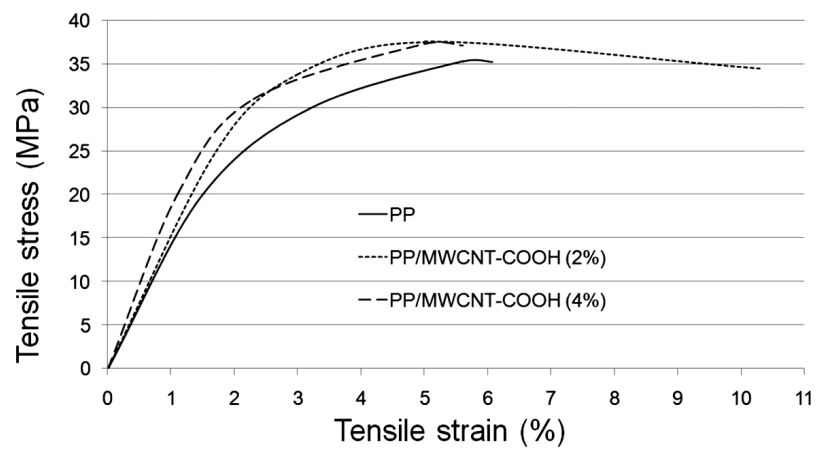

Figure 5: Stress-strain curves corresponding to PP-based nanocomposites

Slika 5: Krivulje napetost - raztezek nanokompozitov na osnovi PP 


\section{E. BAN et al.: MULTI-WALLED CARBON NANOTUBES EFFECT IN POLYPROPYLENE NANOCOMPOSITES}

superior characteristics compared to the bare PP; the increase is more significant for the Young's modulus, while the density remains low.

Table 1: Results for mechanical and thermal stability under load tests Tabela 1: Rezultati mehanske in toplotne stabilnosti pri obremenitvi

\begin{tabular}{|l|c|c|c|}
\hline \multicolumn{1}{|c|}{ Sample } & PP & $\begin{array}{l}\text { PP/MWCNT- } \\
\text { COOH (2 \%) }\end{array}$ & $\begin{array}{c}\text { POMWCNT- } \\
\text { COH (4 \%) }\end{array}$ \\
\hline Density, g/cm ${ }^{3}$ & 0.87 & 0.91 & 0.93 \\
\hline $\begin{array}{l}\text { Tensile stress at } \\
\text { tensile strength, MPa }\end{array}$ & 35.34 & 37.56 & 37.38 \\
\hline $\begin{array}{l}\text { Young's modulus, } \\
\text { MPa }\end{array}$ & 2026.1 & 2307 & 2413.71 \\
\hline $\begin{array}{l}\text { Flexure stress at } \\
\text { tensile strength, MPa }\end{array}$ & 32.51 & 35.42 & 33.59 \\
\hline $\begin{array}{l}\text { Young's flexure } \\
\text { strain, MPa }\end{array}$ & 1439 & 1547.66 & 1575.19 \\
\hline HDT, ${ }^{\circ} \mathrm{C}$ & 66.9 & 69.2 & 70.3 \\
\hline
\end{tabular}

Adding $2 \%$ of mass fractions of MWCNT-COOH generated an increase in the tensile modulus of about $15 \%$ while $4 \%$ of mass fractions of led to a $20 \%$ increase compared to the bare PP. The flexural modulus of the $w=4 \%$ sample presented an increase by $10 \%$, proving that adding MWCNT-COOH leads to stiffer materials.

For the tensile and flexural strengths, the increase values are in the range of 5-9\% for both the 2 and $4 \%$ samples, with slightly higher values for the $2 \%$ sample. This fact can be due to the higher content of the nanofiller, which favors agglomerations, an issue that was probably not overcome with the mechanical dispersion using the extrusion. At the $2 \%$ loading, there is a significant increase in the elongation at break, while at the $4 \%$ loading, both the strength and the elongation at break decrease compared to the $2 \%$ loading, indicating a decrease in the ductility. ${ }^{17}$ At the higher MWCNT content filler-filler agglomerates are likely to act as stressconcentrating sites ${ }^{17}$ as observed in the SEM images,

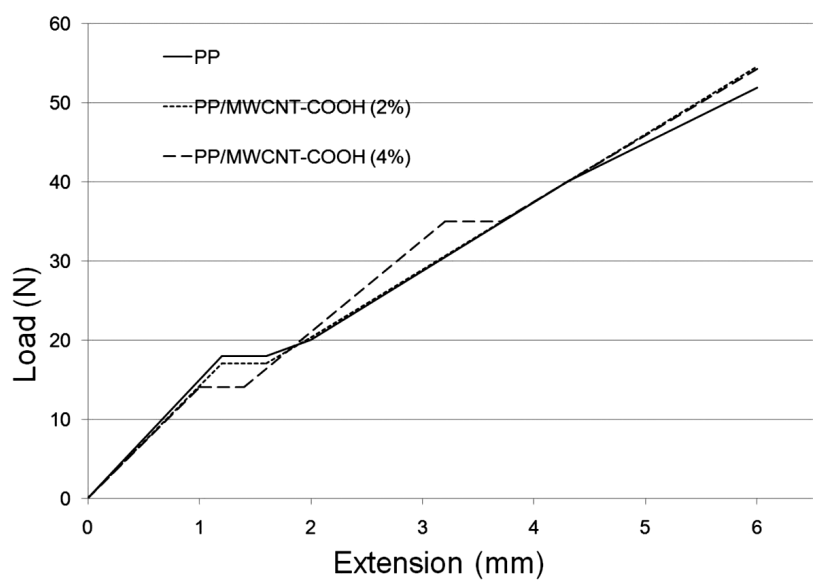

Figure 6: Load-extension evolution during the flexural testing of PP-based nanocomposites

Slika 6: Obnašanje obremenitev - raztezek med upogibnim preizkusom nanokompozitov na osnovi PP resulting in lower strength values. The number of the stress-concentration sites increases with the nanotubes content, leading to a decrease in the elongation. ${ }^{18}$

The mechanical properties show that the composite failure is dependent on the nanofiller content.

\subsection{HDT thermal stability under load}

The thermal stability under load is in concordance with the other test results. There is a minor increase in HDT for the MWCNT sample, from 66.9 to $69.2{ }^{\circ} \mathrm{C}$ for the $2 \%$ loading and $70.3{ }^{\circ} \mathrm{C}$ for the $4 \%$ loading, which is confirmed by the DSC curves of the PP-based materials that present no change in the thermal behavior up to $200{ }^{\circ} \mathrm{C}$.

\subsection{Thermal degradation behavior}

The TG curves from Figure 7a indicate that the materials are thermally stable up to approximately 200-220 ${ }^{\circ} \mathrm{C}$; after this temperature they undergo thermal-degradation processes.

Table 2 summarizes the TG-DSC results, showing that a MWCNT-COOH addition leads to an increase in the initial temperature of the degradation process $\left(T_{\text {onset }}\right)$ on the TG curve of approximately $65{ }^{\circ} \mathrm{C}$. The $50 \%$ weight loss is generally considered to be an indicator of the structural destabilization ${ }^{19}$, which occurs up to
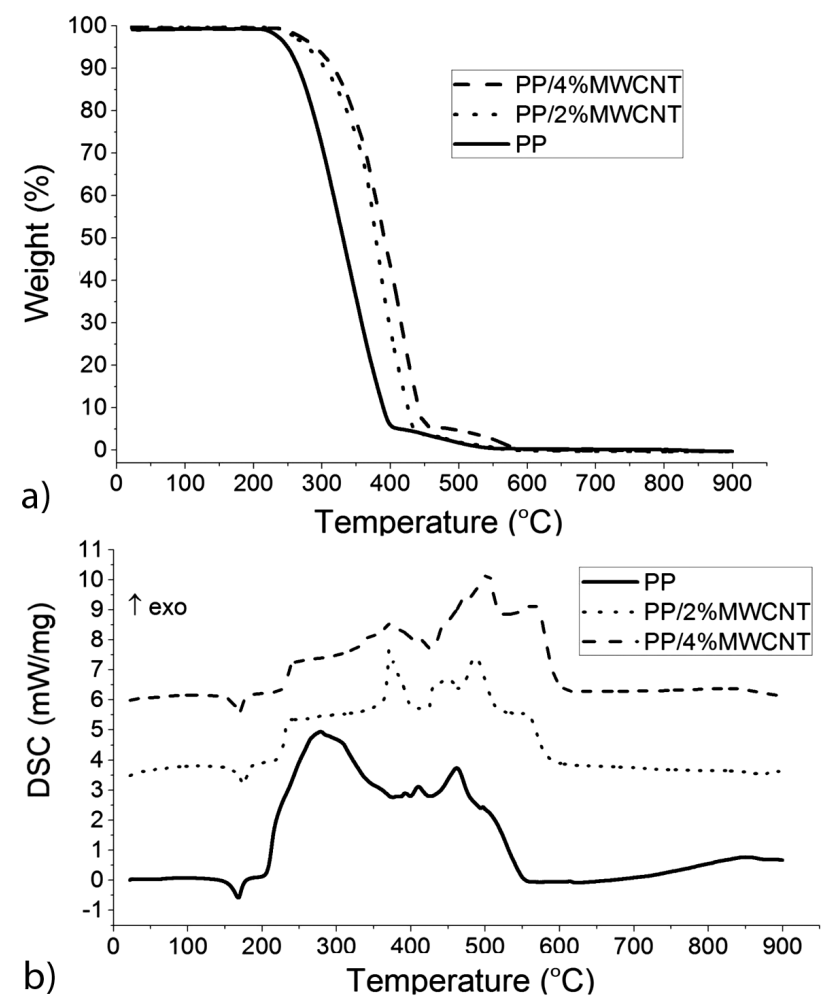

Figure 7: a) TG and b) DSC curves for PP/MWCNT nanocomposites compared to simple PP

Slika 7: a) TG- in b) DSC-krivulje za PP/MWCNT kompozite v primerjavi $\mathrm{z}$ enostavnim PP 
approximately $330{ }^{\circ} \mathrm{C}$ for PP, up to $370{ }^{\circ} \mathrm{C}$ for $\mathrm{PP} / 2 \%$ MWCNT and $390{ }^{\circ} \mathrm{C}$ for PP/4 \% MWCNT. The end of the degradation process $\left(T_{\text {endset }}\right)$ is shifted towards higher values as the MWCNT content increases.

Table 2: TG-DSC analysis results

Tabela 2: Rezultati TG-DSC analiz

\begin{tabular}{|c|c|c|c|c|c|}
\hline Sample & $\begin{array}{c}T_{\text {onset, }} \\
{ }^{\circ} \mathrm{C}\end{array}$ & $\begin{array}{c}T_{\text {endset }} \\
{ }^{\circ} \mathrm{C}\end{array}$ & $\begin{array}{c}T_{\text {melting, }}, \\
{ }^{\circ} \mathrm{C}\end{array}$ & $\begin{array}{c}T_{\text {decomp } 1,}, \\
{ }^{\circ} \mathrm{C}\end{array}$ & $\begin{array}{c}T_{\text {decomp2 }}, \\
{ }^{\circ} \mathrm{C}\end{array}$ \\
\hline PP & 263.3 & 390 & 167.9 & 279.2 & $\begin{array}{c}410 / 461.5 / \\
496.7\end{array}$ \\
\hline $\begin{array}{c}\text { PP/2 \% } \\
\text { MWCNT }\end{array}$ & 326.5 & 408.7 & 166.8 & 362.6 & $\begin{array}{c}441.4 / 487.4 / \\
546.4\end{array}$ \\
\hline $\begin{array}{c}\text { PP/4 \% } \\
\text { MWCNT }\end{array}$ & 327.2 & 441.2 & 167.3 & 365.2 & $\begin{array}{c}471.4 / 500.9 / \\
561.4\end{array}$ \\
\hline
\end{tabular}

In the $25-200{ }^{\circ} \mathrm{C}$ region, an endothermic effect is registered on the DSC curve (Figure 7b), associated with the polymer melting process. As melting is a physical process, the effect is not accompanied by the weight loss. The maximum rate of the endothermic effect is reached at approximately the same temperature (167 ${ }^{\circ} \mathrm{C}$ ) for all the samples, showing that the MWCNT addition does not induce changes in the melting temperature, but the intensities of the corresponding peaks are lower for the MWCNT samples.

In the regions above $200{ }^{\circ} \mathrm{C}$, exothermic effects appear, associated with the decomposition processes that occur in two main stages, mainly between $200-400{ }^{\circ} \mathrm{C}$ and $400-600{ }^{\circ} \mathrm{C}$, divided into several secondary exothermic effects, accompanied by the weight loss. The recorded effects for the PP-based materials are similar, but because of their different compositions, the peak intensities differ.

In the $200-400{ }^{\circ} \mathrm{C}$ region, the maximum weight loss occurs for all the samples, being approximately $94 \%$. On the DSC curve, the peaks corresponding to the exothermic effects are shifted towards higher values; the peak for PP appears at $279{ }^{\circ} \mathrm{C}$, for PP/2 \% MWCNT it appears at $363{ }^{\circ} \mathrm{C}$ and for $\mathrm{PP} / 4 \%$ MWCNT it appears at $365{ }^{\circ} \mathrm{C}$, but with a lower intensity for the MWCNT samples. The increase in the decomposition temperature of the MWCNT nanocomposites could be due to the barrier effect generated by the nanotubes, when they are well dispersed into the matrix, hindering oxygen diffusion and retarding the thermo-oxidative degradation of polypropylene..$^{20,21}$ MWCNT acts as the protective agent against a thermal degradation of polypropylene.

Between $400-600{ }^{\circ} \mathrm{C}$, the exothermic effects are accompanied by a weight change of approximately $6 \%$ for all the samples. Also, in this region, the exothermic effects recorded on the DSC curves of PP/MWCNT appear at higher temperatures and with higher intensities, with the difference increasing with the MWCNT content. This shows that the protective effect is more pronounced at higher temperatures and higher MWCNT contents.

The residual mass is extremely low (up to $w=0.5 \%$ for all the samples), proving that although the
PP/MWCNT nanocomposites burn slower than the bare PP, they burn nearly completely, indicating that the eventual flame-retardancy properties of these materials are probably due to the chemical and physical processes in the condensed phase rather than the gas phase. ${ }^{22}$

The TG-DSC analysis results prove that the addition of MWCNT improves the decomposition temperature of the polypropylene nanocomposites and, consequently, the thermal-degradation resistance.

\section{CONCLUSIONS}

The study presents a characterization of an isotactic polypropylene filled with carboxyl-functionalized MWCNT prepared through the simple and quick way of the melt-extrusion technique. The results show an improvement in the mechanical strength and modulus, thermal stability under load as well as decomposition temperature when adding the nanofiller. In the case of the higher MWCNT loading $(w(\mathrm{MWCNT})=4 \%)$, the nanocomposites exhibited higher stiffness, decomposition temperature and thermal stability under load, while in the case of the lower loading $(w(\mathrm{MWCNT})=2 \%)$ the nanocomposites exhibited better mechanical strengths. The nanocomposites maintained their low-density advantages showing a minor increase when adding the nanofiller. The results prove that the thermoplastic polymers loaded with carbon nanotubes might be a new class of light and strong composites that could find applications in a large variety of fields.

Further compatibilization of the polypropylene matrix by grafting it with different agents such as maleic anhydride, methylstyrene $e^{23}$ and copolymers based on maleic anhydride ${ }^{24}$ can lead to nanocomposites with even higher mechanical and thermal properties, due to an increased matrix-filler adhesion.

\section{Acknowledgments}

This work was funded by the Romanian Ministry of Education through the PN-II-PT-PCCA-168/2012 project "Hybrid composite materials with thermoplastic matrices doped with fibres and disperse nano-fillings for materials with special purposes" and by the Sectoral Operational Programme "Human Resources Development 20072013" of the Ministry of European Funds through the Financial Agreement POSDRU/159/1.5/S/132397.

\section{REFERENCES}

${ }^{1}$ F. Hussain, M. Hojjati, M. Okamoto, R. E. Gorga, J. Compos. Mater., 40 (2006) 17, 1511-1565, doi:10.1177/0021998306067321

${ }^{2}$ E. Logakis, E. Pollatos, Ch. Pandis, V. Peoglos, I. Zuburtikudis, C. G. Delides, A. Vatalis, M. Gjoka, E. Syskakis, K. Viras, P. Pissis, Compos. Sci. Technol., 70 (2010) 2, 328-335, doi:10.1016/ j.compscitech.2009.10.023

${ }^{3}$ A. Szentes, G. Horvath, Cs. Varga, Hungarian Journal of Industrial Chemistry, 38 (2010) 1, 67-70 


\section{E. BAN et al.: MULTI-WALLED CARBON NANOTUBES EFFECT IN POLYPROPYLENE NANOCOMPOSITES}

${ }^{4}$ T. Y. Hwang, H. J. Kim, Y. Ahn, J. W. Lee, Korea-Australia Rheology Journal, 22 (2010) 2, 141-148

${ }^{5}$ D. Bikiaris, A. Vassilou, K. Chrissafis, K. M. Paraskevopoulos, A Jannakoudakis, A. Docoslis, Polym. Degrad. Stab., 93 (2008) 5, 952-967, doi:10.1016/j.polymdegradstab.2008.01.033

${ }^{6}$ S. P. Bao, S. C. Tjong, Mater. Sci. Eng. A, 458 (2007) 1-2, 508-516, doi:10.1016/j.msea.2007.08.050

${ }^{7}$ European Standard SR EN ISO 527-2: Determination of tensile properties of plastics, Test conditions for moulding and extrusion plastics, 2000

${ }^{8}$ European Standard SR EN ISO 178: Plastics, Determination of flexural properties, 2003

${ }^{9}$ F. Ozmihci, Polypropylene - Natural Zeolite Composite Films, Dissertation Thesis, Materials Science and Engineering Department, Izmir Institute of Technology, 1999, p. 48

${ }^{10}$ I. Karacan, H. Benli, The use of infrared-spectroscopy technique for the structural characterization of isotactic polypropylene fibres, Journal of Textile \& Apparel, 21 (2011) 2, 116-123

${ }^{11}$ G. Parthasarthy, M. Sevegney, R. M. Kannan, J. Polym. Sci., Part B: Polym. Phys., 40 (2002) 22, 2539-2551, doi:10.1002/polb.10304

${ }^{12}$ A. R. Horrocks, J. A. D'souza, J. Appl. Polym. Sci., 42 (1991) 1, 243-261, doi:10.1002/app.1991.070420129

${ }^{13}$ L. V. Diyakon, O. P. Dmytrenko, N. P. Kulish, Yu. I. Prylutskyy, Yu. E. Grabovskiy, N. M. Belyy, S. A. Alekseev, A. N. Alekseev, Yu. I. Sementsov, N. A. Gavrylyuk, V. V. Shlapatskaya, L. Valkunas, R. Ritter, P. Scharff, Functional Materials, 15 (2008) 2, 169-174

${ }^{14}$ V. T. Le, C. L. Ngo, Q. T. Le, T. T. Ngo, D. N. Nguyen, M. T. Vu, Adv. Nat. Sci.: Nanosci. Nanotechnol, 4 (2013) 3, 1-5, doi:10.1088/ 2043-6262/4/3/035017
${ }^{15}$ S. C. Her, C. Y. Lai, Materials, 6 (2013) 6, 2274-2284, doi:10.3390/ ma6062274

${ }^{16}$ C. R. Biswal, K. Mishra, P. L. Nayak, Synthesis and Characterization of Modified Multi-Walled Carbon Nanotubes Filled Thermoplastic Natural Rubber Composite, Middle-East Journal of Scientific Research, 18 (2013) 2, 168-176, doi:10.5829/idosi.mejsr.2013.18. 2.12431

${ }^{17}$ S. A. Girei, S. P. Thomas, M. A. Atieh, K. Mezghani, S. K. De, S. Bandyopadhyay, A. Al-Juhani, J. Thermoplast. Compos. Mater., 25 (2012) 3, 333-350, doi:10.1177/0892705711406159

${ }^{18}$ S. R. Katti, B. K. Sridhara, L. Krishnamurthy, G. L. Shekar, Mechanical Behaviour of MWCNT Filled Polypropylene Thermoplastic Composites, Indian Journal of Advances in Chemical Science, 2 (2014), 6-8

${ }^{19}$ E. M. Sabri, O. Emel, Fibres \& Textiles in Eastern Europe, 21 (2013) 2, 22-27

${ }^{20}$ F. Avalos-Belmontes, L. F. Ramos-deValle, E. Ramirez-Vargas, S. Sanchez-Valdes, J. Mendez-Nonel, R. Zitzumbo-Guzman, Journal of Nanomaterials, 2012 (2012), 1-8, doi:10.1155/2012/406214

${ }^{21}$ N. Khelidj, X. Colin, L. Audouin, J. Verdu, C. Monchy-Leroy, V. Prunier, Polym. Degrad. and Stab., 91 (2006) 7, 1593-1597, doi:10.1016/j.polymdegradstab.2005.09.011

${ }^{22}$ T. Kashiwagi, E. Grulke, J. Hilding, R. Harris, W. Awad, J. Douglas, Macromol. Rapid Commun., 23 (2002) 13, 761-765

${ }^{23}$ E. Manias, A. Touny, L. Wu, K. Strawhecker, B. Lu, T. C. Chung, Chem. Mater., 13 (2001) 10, 3516-3523, doi:10.1021/cm0110627

${ }^{24}$ A. Szentes, C. Varga, G. Horváth, L. Bartha, Z. Kónya, H. Haspel, J. Szél, Á. Kukovecz, eXPRESS Polymer Letters, 6 (2012) 6, 494-502, doi:10.3144/expresspolymlett.2012.52 